\title{
Industry Involvement Conceptual Framework for Collaboration of National Dual Training Systems (NDTS) in Malaysia
}

\author{
Sariyah Adam*, Mohamad Sattar Rasul, Ruhizan Mohamad Yassin \\ Faculty of Education, National University of Malaysia, Bandar Baru Bangi, Selangor, Malaysia \\ *Corresponding author: sariyah@mohr.gov.my
}

\begin{abstract}
The issue of industry involvement in skills training programs since the 1950s has shown the level of industry involvement is still low in Malaysia. The government's efforts to involve high finance allocation in encouraging industry involvement also did not show good results. In 9th Malaysia Plan (20052010), the Economic Planning Unit (EPU) is targeting 6,300 industries to engage in National Dual Training System (NDTS) program. However, data from NDTS Q-Fact showed that until the end of the 2010, only 1,028 industries involved. In fact, until the end of the 10th Malaysia Plan in 2015, only 3,775 industries involved. This article proposed the framework for industry involvement collaboration of the NDTS programme in Malaysia. The method used in this article is a systematic review that takes previous studies on industry involvement in skills training collaboration into consideration. The framework built based on the organisation factors that influence the involvement of industry that described in these three variables: organisational governance, organisational motivation, organisational behaviour. Construct for each variable will be explained to see its relations with industrial involvement in the aspect of collaboration. Key findings from this study will form a strategic indicator of industrial involvement in implementation of NDTS programme in Malaysia.
\end{abstract}

Keywords: Organization governance, motivation, organization behavior, industry collaboration, NDTS

\begin{abstract}
Abstrak
Isu penglibatan industri dalam program latihan kemahiran di Malaysia sejak tahun 1950-an menunjukkan tahap penglibatan industri masih rendah. Usaha kerajaan dalam menggalakkan penglibatan industri juga tidak menunjukkan hasil yang baik malah telah melibatkan peruntukan kewangan yang tinggi. Dalam Rancangan Malaysia ke-9 (2005-2010), Unit Perancang Ekonomi (UPE) mensasarkan 6,300 industri untuk melibatkan diri dalam program Sistem Latihan Dual Nasional (SLDN). Walau bagaimanapun, data dari Q-Fact SLDN menunjukkan bahawa sehingga akhir tahun 2010, hanya 1,028 sahaja industri yang terlibat. Malah, sehingga akhir Rancangan Malaysia Ke-10 pada 2015, hanya 3,775 industri sahaja yang terlibat. Artikel ini mencadangkan kerangka keterlibatan industri dalam kerjasama program SLDN di Malaysia. Kaedah yang digunakan dalam artikel ini adalah satu semakan secara sistematik yang mengambil kira kajian sebelum ini mengenai keterlibatan industri dalam kerjasama latihan kemahiran. Kerangka yang dibina berdasarkan faktor-faktor organisasi yang mempengaruhi keterlibatan industri yang merangkumi tiga pembolehubah: tadbir urus organisasi, motivasi organisasi, tingkah laku organisasi. Konstruk bagi setiap pembolehubah diterangkan untuk melihat hubungannya dengan keterlibatan industri dalam kerjasama. Penemuan utama daripada kajian ini akan membentuk satu indikator strategik keterlibatan industri dalam pelaksanaan program SLDN di Malaysia.
\end{abstract}

Kata kunci: Tadbir urus organisasi, motivasi, tingkahlaku organisasi, kerjasama industri, SLDN

C 2017 Penerbit UTM Press. All rights reserved

\subsection{INTRODUCTION}

Studies have shown that companies that collaborate with universities usually have higher productivity than companies that do not have such collaboration (Malairaja and Zawdie, 2008). Companies that collaborate also enjoy greater benefits in terms of research and development $(\mathrm{R} \& \mathrm{D})$ and able to produce quality products at competitive costs. The interaction that exists between research institutions and industry in collaboration is considered as a strategic tool for competitive innovation. Government research policy also emphasizes collaboration between universities and industry as key policies in promoting innovation (Rast et al., 2012). Collaboration includes how to solve problems in community and organizations, providing an attractive research environment and contribute in the form of creative concepts. Gray (1989) defines collaboration as a process where two parties look at the problem in a positive and they were able to receive the difference between them and they can work together to find solutions that go beyond their own limited vision.

In Malaysia, industry-based training had long been extant. Involvement in the training industry in Malaysia has started from 1957 when the National Apprenticeship Scheme (NAS) is introduced. The Government has set to mainstream skills training as a key result areas in the $10^{\text {th }}$ Malaysia Plan, which build and maintain world class human capital to produce a composition of highly skilled workers from $28 \%$ to $33 \%$ by 2015 and $50 \%$ by 2020 (RMK-10, 2010). However, scenario in Malaysia indicates that industry involvement in skills training is still less encouraging based on past studies (Tan, 1991; World Bank, 1997; NDTS Q-Fact 2010; DSD 2012a). Hence, this paper review is based on previous studies in Malaysia and abroad in skills training before being adapted to the implementation of the NDTS program which will focus on the organization factors at industry that affect industry involvement in NDTS program collaboration. 


\subsection{RESEARCH BACKGROUND}

Past studies have found the issue of governance is one of the dominant factors in the industry's involvement skills training collaboration program. According to Ansell, C. \& Gash, A. (2008) in meta-analysis studies of 137 cases of governance collaboration, they found the governance of an organization influences the involvement of two parties to work together and the variables that affect the governance of the organization are leadership, commitment, trust and coordination. The industry involvement in foreign countries show the industry support and close cooperation in the implementation of training programs. According to Kim (2010), through his study of barriers in collaboration between industry and training center in South Korea, one of the most important issues related to the collaboration is the behavior of different organizations. Robbins (2005) state that, organizational behavior is a field of study that researching the impact caused by the behavior of individuals, groups and structures within the organization to apply specific knowledge to ensure the progress and efficiency of an organization.

Organizational behavior in countries such as Germany, Australia and Switzerland not only focus on profit but rather a social responsibility to society for the development of young generation. In Germany, employers spend half the cost of running a dual training system, which is almost equivalent to the provisions given by the government. Schmidt \& Alex (1997) stated that dual training system in Germany is based on the close relationship between public and private training organizations and the participation of industry is voluntary. Strong collaboration and involvement between industry and training center is a recipe for success in dual training system conducted abroad. According to theory of planned behavior, there are three main elements that affect the intention someone to engage, that is the attitude toward the behavior, subjective norms, and perceived behavioral control (Glanz et al., 2008).

The government has implemented various measures to motivate the industry engaging in NDTS program collaboration. Motivation determines governance and behaviorial of the organization willing to engage and collaborate. However, from the data obtained in NDTS division, found that industry is keen to get involved when offered for profit. The proof is when government discontinue incentives to apprentices and trainees in 2010, the participation of apprentices dropped sharply from 15,705 to 1293 and from industry 642 to 46 industry compared to the previous year. It is closely related to discontinuation of monthly incentive allowance to apprentices and industry in 2010.

NDTS first introduced in 2005 in accordance to develop human capital in Malaysia who are highly skilled and knowledgeable. NDTS implementation of skills training has changed the landscape in terms of fulfilling the needs of industry and the development of competitive skilled human capital (DSD, 2012b). NDTS execution method involves learning in two situations, namely $20 \%-30 \%$ theoretical at training institutions and 70\% - 80\% practical training at industry either for day-release or block-release (DSD, 2011). This program is student centered concept that provided an opportunity for apprentices to gain a better understanding of the theory and application of technical skills learned in real work situations. The applied learning approach in NDTS program can reduce skilled workforce disbursements that do not meet the current needs and also the exposure of the real employment situation in the industry (George, 2007; Rahim M. Sail et al. 2007; DSD, 2006). In fact, NDTS can overcome the problem of skilled manpower disbursements to meet current requirements as well as industry to reduce the cost of unemployment (Loose, Spottl and Yusoff Md Tahir, 2008).

\subsection{PROBLEM STATEMENT}

Results from previous studies have found that the level of industry involvement in training is still low (Tan, 1991; World Bank, 1997; NDTS Q-Fact, 2010; DSD, 2012a). Issues of these studies are discussed below.

\section{Commitment Issue}

In Malaysia, the industry involvement in skills training was started over 50 years ago and is known for apprenticeship system. National Apprenticeship Scheme (NAS) has been introduced in Malaysia in 1957 and is administered by the Central Apprenticeship Board (CAB). Through this scheme, the government provides free training to industry and industry can sponsor their apprenticeship and adopt training facilities provided by the government (Fong, 1986). Due to the encouraging apprentices issue, the government has decided to increase the number of Industrial Training Institute (ITI) in order to accommodate the increasing number of apprentices in the NAS. However, when ITI has been completed, the output of apprentices show a decline.

Table 1 shows the number of apprentices decline started in 1983 after an increase ITI completely built. Eventually, in 1987, the number of apprentices who lived only 73 people. The participation of apprentices for this program is getting less and eventually dismissed NAS program. Report of the Ministry of Labour and Manpower in (1980) state NAS had to be dismissed due to lack of industry taking part in a joint training with the Industrial Training Institute.

Table 1 Output apprentice of NAS Scheme 1979-1987

\begin{tabular}{|c|c|c|c|}
\hline Year & No. of apprentices completing NAS & No. ITI & Duration \\
\hline 1979 & 219 & 2 & 4 year \\
\hline 1980 & 280 & 2 & 4 year \\
\hline 1983 & 243 & 3 & 3 year \\
\hline 1984 & 135 & 3 & 3 year \\
\hline 1987 & 73 & 7 & 3 year \\
\hline
\end{tabular}

Source: Ministry of Labour and Employment Report, 1980

In addition, the results of a study conducted by Department of Skills Development (DSD) in 2012 on the involvement of Government Link Company (GLC) and the Multinational Company (MNC) in the NDTS shows that the commitment of GLCs and MNCs to engage in 
NDTS program is still low (DSD, 2012c). In 2011, only 5.9\% GLC (25 companies) and MNC (60 companies) involved in NDTS program. For comparison, according to data from the Companies Commission of Malaysia (CCM) in 2011 there were 509 GLCs and 4,430 MNCs operating in Malaysia (DSD, 2012c).

\section{Incentive Issue}

The issue of incentives is one of the dominant issues in the involvement of the industry to provide training. This issue started when the government launched the Industrial Master Plan (IMP) in 1985 until NDTS introduced in 2005, this issue is still relevant. According to Ahmad Othman and Morgan (1998), the Industrial Master Plan (IMP) in 1985 are to formulate industrial strategy for the period of 19861995, and the focus is to improve the industry towards use of high technology and industrial incentive capital as well as less dependence on labor incentive. To support that effort, Double Tax Deduction Incentive (DDIT) scheme was introduced in 1986 with the hope that they will benefit the industry. Table 2 shows the percentage spent by manufacturing sector company in training.

Table 2 Percentage spent by manufacturing sector company in training.

\begin{tabular}{ll} 
Not spend for training & $42.8 \%$ \\
\hline Spend $1 \%$ of payroll for training & $19.3 \%$ \\
\hline Spend $2 \%-5 \%$ of payroll for training & $27.9 \%$ \\
\hline Spend $6 \%-10 \%$ of payroll for training & $7.1 \%$ \\
\hline Spend $10 \%$ of payroll for training & $2.9 \%$ \\
\hline
\end{tabular}

Through a survey conducted by the Association of Malaysian Manufacturers on achievements, problems and prospects of the 140 companies in the Manufacturing Sector in 1991 found that the company did not take advantage of the government's efforts to provide training to employees (Tan, 1991). Also demonstrates the government's efforts to introduce the Double Tax Deduction Incentive (DDIT) scheme did not achieve the goal.

Related matters about incentives are also on view during the NDTS implementation started 2005. The initial goal of the NDTS program is to produce a number of 31,500 skilled workers and 6,300 industry involved by 2010 (NVTC, 2005). However until the end of 2010, the overall number of apprentices only 25,021 and 1028 industry involved (NDTS Q-Fact, 2010). According to Table 3, the participation of apprentices dropped sharply from 15,705 to 1293 and from 642 to 46 industry compared to the previous year. According to the Economic Planning Unit (EPU) it is closely related to discontinuation of monthly incentive allowance to apprentices and industry in 2010. This shows that the incentives issue is still a factor in the industry's involvement in training collaboration.

Table 3 Apprentices and industry statistics participation in 9th Malaysia Plan (2005-2010)

\begin{tabular}{|c|c|c|c|c|}
\hline \multirow{2}{*}{ Year } & \multicolumn{2}{|c|}{ No. Participation } & \multicolumn{2}{c|}{ Total } \\
\cline { 2 - 5 } & Apprentice & Industry & Apprentice & Industry \\
\hline 2005 & 70 & 4 & 70 & 4 \\
\hline 2006 & 163 & 3 & 233 & 7 \\
\hline 2007 & 1878 & 36 & 2111 & 43 \\
\hline 2008 & 5912 & 297 & 8023 & 340 \\
\hline 2009 & 15705 & 642 & 23728 & 982 \\
\hline 2010 & 1293 & 46 & 25021 & 1028 \\
\hline
\end{tabular}

In fact, until the end of the 10th Malaysia Plan in 2015, only 3,775 industries involved in NDTS program (NDTS Q-Fact, 2015). The number is still low and insufficient to meet the country's need for skilled workers.

\section{Administrative Issue}

In 2012, 253 companies has been visited by DSD to identify, promote and create a strategic partnership with industry. The output from the visits found that 145 companies (57\%) out of 253 companies are interested to collaborate with the department. While 96 companies (38\%) were not interested to collaborate and another 12 companies (5\%) request to be revisited (DSD, 2012a). That 145 companies also expressed concern over the obstacle and constraint that future financial factors that may exist in the future as they have to consider the administrative burden resulting from this cooperation. Response from the 145 companies as shown in Table 4.

Table 4 Industry future constraints in collaborative activities

Financial $49.7 \%$

\begin{tabular}{ll}
\hline Time constraint & $49.1 \%$ \\
\hline Lack of technology, facilities and human resources & $27.6 \%$ \\
\hline Lack of expertise & $20.7 \%$ \\
\hline Bureaucracy & $17.2 \%$ \\
\hline Company confidentiality & $9.7 \%$ \\
\hline
\end{tabular}




\subsection{RESEARCH OBJECTIVES}

To identify factors that affects the industry in Malaysia to collaborate in skills training and establishing a framework of industry involvement in the NDTS program. The main objective is to identify the organizational factors as the cause of the gap for industry involvement in the implementation of the NDTS program as well as the industry involvement framework. In relation of that a few objectives were set:

i. To identify the organization governance factors/issues that affect the involvement of industry in the implementation of the NDTS program.

ii. To identify the motivation factors/issues that affect the involvement of industry in the implementation of the NDTS program.

iii. To identify the organization behavior factors/issues that affect the involvement of industry in the implementation of the NDTS program.

iv. To build conceptual framework based on the factors that affect the involvement of industry in the implementation of the NDTS program.

\subsection{METHODOLOGY}

Methodology used in this article is a systematic review. This systematic review was used to collect and analyze critically research studies. This method is also suitable for analyzing the existing studies faster and cheaper than starting a new study. Methods that are selected before one or more research questions are formulated, and then aim to find and analyze studies that relate to and answer those questions. Researcher seeking information about industry involvement in skills training collaboration, includes government reports, proceedings papers, journals and electronic references. For searching electronic articles, three journal database used, EMERALD, Taylor \& Francis and ScienceDirect. This search is carried out using five keywords that the organization governance, motivation, organizational behavior, industrial collaboration, NDTS. By using document analysis, various documents have been used to obtain a general idea and perspective in this study. According to Bowen (2009), document analysis involves three phases observed (initial examination), read (comprehensive examination) and interpretation of the findings so that it can be analyzed and summarized in a comprehensive manner. All of these process help researchers get the best review in producing this study.

\subsection{FINDING}

Based on its initial industry involvement in skills training programs, incentives given by the government and policy established clearly shows various efforts have been made to encourage the involvement of industry. Issues and success factors of abroad industry in the industry's involvement through training programs proven that organizational factors has a strong influence. However, there is still no specific studies that focus on organizational factors as the cause of the industry's involvement and the scenario itself is the problem of the gap for industry involvement in the implementation of the NDTS program in Malaysia. Therefore, this study will focus on the implementation of the NDTS program to identify organizational factors that influence the involvement of industry, the relationship between the organization governance, motivation and organization behavior that affect the involvement of industry and eventually establish indicator strategic industry involvement in the implementation of the NDTS program.

\section{Organizational Governance}

Governance is a joint venture involving the design and use of structure and process that allows someone to lead, coordinate and allocate resources for the overall collaboration with consider all the activities involved (Vangen et al. 2014). A key feature of collaboration between organizations is that they are administered without involving the hierarchy (Provan and Kenis, 2008). Erik-Hans Klijn (2008) emphasized that governance is carried out through a win-win relationship rather than correcting elements of the existing bureaucracy. Collaboration governance emphasizes leadership and management that suggest the need to consider the inclusion of stakeholders, trust, coordination, commitment in the same direction and goals to ensure the collaboration of governance are transparent (Vangen et al. 2014). Thus, the leadership, trust, coordination and commitment will be assessed its relationship with industry involvement in the implementation of the NDTS program.

Leadership

Leadership is important to establish and maintain a clear ground rules, build trust, facilitate communication, and explore mutual benefits. Vangen and Huxham (2003) argues that leadership is important to control, authorize the involvement of stakeholders and then move the collaboration forward. Weiss (2002) identifying leadership is the most important factor in stimulating collaborative interaction. They describe the interactions in terms of achievement of collaboration, including the partners to think in new and better ways to achieve the goals, plans and integrate programs to achieve better results. They introduced the concept of leadership competencies that are measured based on the following items, which are to take responsibility for the work; inspire and motivate partners; empower partners; strive to create a harmonious atmosphere in collaboration; foster respect and trust; promote inclusiveness and openness; create an environment where the difference opinion can be voiced; resolve conflicts between partners; combining perspectives, resources and skills of partners; and help partners reframe issues and creative in developing new methods to the key issues. This concept has also been supported by (Alter \& Hage, 1993; Chrislip \& Larson, 1994). Leadership factors influencing the indeed sharing knowledge among members of the organization (Connelly and Kelloway, 2003; Murray, 2003). These factors include the leadership style such as gender and the willingness of leaders to give support to member organizations to share knowledge (Connelly and Kelloway, 2003). Various studies have found that 
the relationship between the leader-employee will generate a high level of support for the leader, improve mutual communication, generate commitment and high performance of subordinates (Gerstner and Day 1994; Schriesheim, Castro, and Cogliser 1999).

\section{Commitment}

Collaboration involving organizational commitment is to reduce competition and achieve common objectives (Bennett and Jayes, 1995). The link between working conditions and commitments have been assessed in studies of organizations (eg, Hackman and Oldham 1980; Mowday, Porter \& Steers, 1982). According to Buchanan (1974), commitment is part of goals and values of the organization, with the role of someone who sets goals and values to the organization so that the values and goals of the organization can be achieved. Organizations that high involvement from its members will create a sense of responsibility and ownership. Furthermore, from a feeling of ownership will produce personnel who commit with a vengeance to the organization. As a result, the employee will produce a committed and believe in the goals and values, comply voluntarily, impose huge effort unexpected, and very eager to remain committed to the organization (Kanter, 1968; Mowday et al, 1982). Voluntary commitments related to intrinsic motivation, where the rewards to be gained from commitment shown and not because control of others (Deci \& Ryan, 1985). In a partnership, organizational commitment is at the core of a successful collaboration. Commitment by Porter (1968), view it as the willingness of employees to provide the level of services for the organization, as well as a strong desire to work together to achieve the organization's main goals and values. Sheldon (1971) see it as a very positive assessment of the organization and intends to work towards achieving the goals set. Although the terms used vary widely, a case study shows that the level of commitment of stakeholders in the partnership is an important variable in determining the success or failure (Gunton and Day 2003; Margerum 2001). Commitment create trust or win-win situation through the best method to achieve the expected results (Burger et al. 2001). Weak commitment to collaboration, particularly at the headquarters level, often seen as the cause of existence of the problem (Yaffee and Wondolleck 2003).

Trust

An important aspect of the relationship collaboration is identifying partners who can be trusted to join. First stage is trusting others among organizations that aim to work together in specific collaboration opportunities are essential conditions that must be used (Msanjila 2009) which refers to the belief between two organizations. The second stage is the level of confidence that refers to the trust level of trustee organization in a relationship based on an assessment set of trust values criteria. When the confidence level is assessed for a specific purpose and this assessment is based on trust specific criteria for a specific purpose, the results of the confidence level for the organization is rated as a certain trust. The third stage is refers to the assessment of organization inspection reliability using specific indicators. Various approaches were used to assess the level of trust in different entities. The one of which was proposed by various criteria approach to analyze trust in the organization. Based on this approach, the rational mechanisms have been developed to assess the level of trust in the organization. While the fourth stage was a trusting relationship that refers to a condition that links between a person or organization, involving mutual dealings between them. Here, a relationship of trust refers to the link condition between trust and the trustee who has the power and features based on the level of trust. Creating trust among organizations is a basic necessity for organizations that participate in the formation of a goal-oriented collaboration network, to respond to market opportunities, through cooperation established (Msanjila, \& Afsarmanesh 2011). But the trust between the two organizations need time to evolve.

\section{Coordination}

Coordination is an essential element for ensuring smooth cooperation process. Coordination perspective emphasizes the specific methods to implement and operate the collaborative relationship that should be emphasized in the administration of the organization. The challenge for coordination is not easy to resolve because it involves many parties in the partnership (Heath \& Staudenmayer, 2000; Kretschmer \& Purana, 2008). There is an alternative view that collaboration between the organizations, which assume coordination among experts as a collaborative effort of integration (Gulati, 2007; Gulati, 2010; Gulati and Singh, 1998). The effect of the lack of coordination will create an imbalance of power. The imbalance of power will bring issues to the parties who do not have the infrastructure organizations represented in the governance process collaboration. English (2000) believes that the more parties involved in a collaborative relationships increasingly difficult coordination of the collaboration. In many cases, the parties are not represented by individual collectively (buanes et al, 2004; Rogers et al 1993).

\section{Organizational Motivation}

From a socio-cultural perspective, motivation is not to be found solely on the individual self, but in individual interaction with others that involve significant activities (Dembo \& Eaton, 1997). Paris and Turner (1994) stated that working together is important where social interaction is motivation. Mitchell (1982) defines motivation as the person who wants and chooses to engage in behavior that stated. A study by Bandura (1996) have found that successfull person is someone more motivated than those who lack motivation. Flynn et al. (2003) asserts that negative thinking will affect motivation. There are a lot of motivation framework can be found within the study, but the majority are related to the study by Deci and Ryan (1985). The framework divide motivation into two main categories: intrinsic motivation and extrinsic motivation.

\section{Intrinsic Motivation}

Intrinsic motivation refers to the extent to which a person is involved in a project or activity which is basically interesting and fun (Klinger, 2006; Ryan \& Deci, 2000). In contrast, extrinsic motivation refers to the context of the task or activity conducted by individuals primarily for external reasons to get a reward or avoid punishment. Intrinsic motivation comes from positive response task itself; other than intrinsically motivated individuals who are engaged in it, especially involving their own interests (Lepper, Greene, \& Nisbett, 1978). 
Intrinsically motivated individuals will enjoy the assignment, trying to find new solutions and use energy in exploring the problem of finding creative solutions (Hennessey, 2000; Staw, 1990;. Woodman et al, 1993). As is well known NDTS program is an adaptation of the German dual system program undertaken voluntarily by the industry there. The industry in Malaysia in this case seen as not ready for this social responsibility. Therefore hoped that intrinsic motivation factors in the study will provide an opportunity for researchers to understand why in principle the industry has not yet reached that stage.

\section{Extrinsic Motivation}

Extrinsic motivation is the individual's perception of the behavior and acceptance of extrinsic rewards such as money and credit plays an important role (Deci \& Ryan, 1985). This motivation usually reduces the individual creativity (Amabile, 1988; Collins and Amabile, 1999; Hennessey, 2000) because they tend to focus on the reward rather than on the task being performed (Amabile, 1996). As a result, individuals can't develop tasks related to creativity and / or may exhibit other forms of cognitive rigidity where their efforts is limited to focus only on the task that has been done in the past (Hogarth, 1987; Staw 1990; Woodman et al., 1993). Continued efforts of the government to provide incentives to industries involved in the implementation of the NDTS program help the industry to get involved. Thus, extrinsic motivation factor should be studied to see how these factors affect the industry's involvement in the implementation of the NDTS program.

\section{Organizational Behavior}

Robbins (2005) define organizational behavior as a field of study that is researching the impact caused by the behavior of individuals, groups and organizational structure in order to use certain knowledge by ensure the progress and efficiency of an organization. George \& Jones (2008) defined organizational behavior as a field that focuses on increasing knowledge using the scientific method on all people of the organization. Thus, the behavior of the organization can be defined as a field of multi-disciplinary studies use scientific methods to study and understand the behavior of individuals and groups involved in the organization process, the factors that influence it, the implications of behavioral and organizational processes as well as methods to improve development and personnel management aims to improve the overall productivity of the organization continuously (Ahmad Sukri, 2002).

\section{Attitude Toward Behavior}

Attitude toward behavior is the result of the belief that implementing a behavior will bring it to certain results, and evaluation of the results. According to Rosenberg and Hovland (1963), the attitude is typically defined as the tendency to react in a certain way towards a particular object. Fishbein and Ajzen (1975) defines a person's attitude as an important trust in a given time. Mitchell and Olson (1981) says that attitude is an internal assessment of an individual. Fishbein and Ajzen (1975) also expressed the attitude is a tendency to be learn to respond in a consistent way, either good or vice versa. This explanation describes the three basic characteristics of the notion that attitudes can be taught, attitude can lead to actions (behavior) and the action is consistently favorably or unfavorably towards the object (Fishbein \& Ajzen, 1975). Attitude is usually seen as the basic variables that are assumed to guide or affect the behavior (Fishbein \& Ajzen, 1975). Lindenmann (2002), states that studies attitudes not only depend on what is said by someone about something, but also what they think and how they tend to act (motivation / inclination). Attitude shown in the organization will encourage organizations to act to engage in cooperation. Thus, the attitude is a factor that needs to be examined whether or not it will impact on the industry to engage in an exercise NDTS program.

\section{Subjective Norm}

Subjective norms are the result of normative beliefs from a a person to trust someone else when necessary (or should not) to perform the behavior (Ajzen and Fishbein, 1980), and motivation to comply with the referred person. Ajzen \& Fishbein (1988) states that the subjective norm refers to the belief of most individual behavior. It relates to the belief to the people around him who will engage in behavior that is acceptable in a group. In the subjective norm there are two important aspects of normative trust and motivation to comply. It is the view of others that are considered important by individuals who advise individuals to display or not display certain behaviors. It also refers to the motivational aspects of the individual's willingness to carry out or not carry out the opinions of others that are considered important about how a person should behave. According to Fishbein \& Ajzen (1975), the role of subjective norm on intention to approach motivation to adhere to reflect individual circumstances whether to comply with the views of others who have influence in his life or not. Individuals who have high motivation to adhere to the view or the role of another person with the intent higher to act (Shook \& Britanu, 2008).

\section{Perceived Behavioral Control}

Perceived behavioral control refers to the perception of other people viewing pleasure or difficulty a person to perform the behavior (Ajzen, 1991). If the behavior is not under the control of the will, one must have the support and the opportunity to perform the behavior. This assumption is a reflection of the experiences that have happened before and expected obstacles. The perception that state whether they have the support and opportunity to affect their intention to perform the behavior, as well as the success and implementation of such behavior. Perceived behavioral control can affect behavior directly or indirectly through intention. Direct connections from behavior perception control expected exists when there is alignment between perception and actual control of a person on a behavior. Perceived behavioral control states that motivation is influenced by how a person feels the difficulty level displaying certain behavior. Perceived behavioral control is determined by the trust control (Control) and the Power of Perception (Perceived Power). The perceive power will generate trust and intention (motivation) to act in any matter while trust control is perceived presence or absence of resources and 
opportunities necessary to carry out the behavior. Facilitating visits is an assessment of the importance of resources to achieve results (Ajzen and Madden, 1986).

Past studies have shown that individual characteristics affect collaboration as it affects the behavior of a collaboration (Esteve et al., 2013). According to Howard et al. (2006), expected benefits when working with something considered as motivation for participation and is believed to have a positive effect that can promote and change the behavior of a person. Findings Crook (2000) states that a person who intentionally increase their motivation is easier to work together.

This coincides with the findings of Howard et al. (2006) and Esteve et al. (2013) which states that the factors of organizational governance variables and behavioral factors associated with organizational motivation help organizations to work together. In conclusion, as stated and explained earlier, the organization governance, organization motivation and organization behavior factors have an influence on industry involvement (Ansell, C. \& Gash, A., 2008; Crok, 2000; Glanz et al., 2008). Based on the literature review, the framework for research are form as shown in Figure 1.

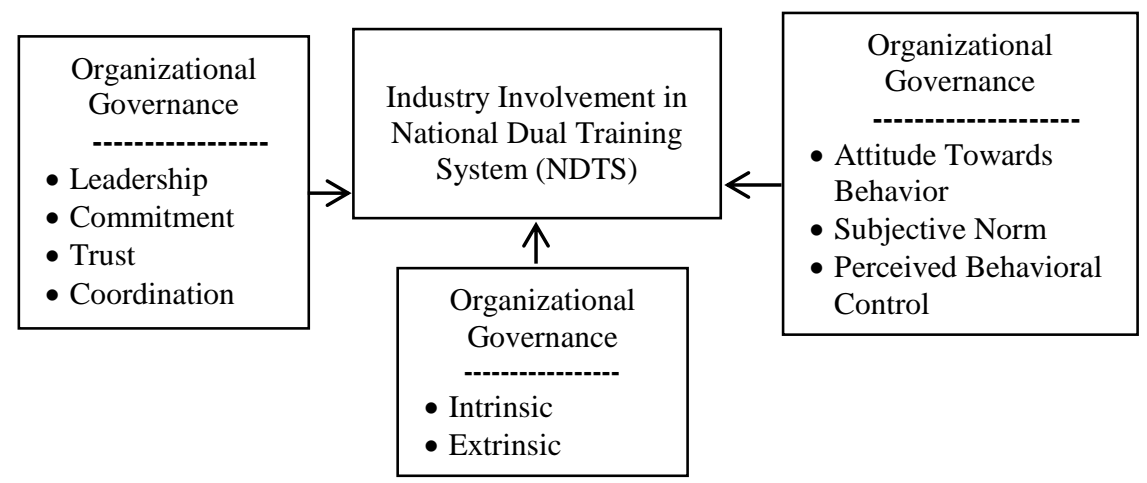

Figure 1 Conceptual framework

\subsection{CONCLUSION}

Industry involvement will impact the success of the NDTS program to achieve the transformation of skills training in Malaysia. Past studies and the success of the industry-based training programs abroad prove that the organization is a major factor that encourages the involvement of the industry to collaborate. Thus, from the framework, organizational governance, organizational motivation and organizational behavior are three elements that need to be addressed in studies to encourage industry involvement in Malaysia to collaborate in NDTS program. However, in future studies, researchers can examine the willingness of industry to adopt involvement by develop model of industry involvement in skills training to consider various other factor than organizational factor. Besides the obstacles and challenges of industry involvement to collaborate, DSD will take an efforts continuously to emphasized on strengthening industry's cooperation promote the NDTS program to the higher level.

\section{References}

Ahmad Othman dan Morgan. (1998). "Employers and the State in Malaysia: Towards a partnership in human resource development." The Malaysian Education Research Association (MERA) Inaugural Conference, Universiti Sains Malaysia Pulau Pinang.

Ahmad Shukri Mohd Nain. (2002). Organization Behavior. Johor: UTM

Ajzen, I., Fishbein, M., Commission, F. T. \& Communications, W. (1988). Theory of Planned Behavior, Is it Relevant? 1-26.

Ajzen, I. (1991). The Theory Of Planned Behavior. Organizational Behavior and Human Decision Processes, 50, $179-211$.

Ajzen, I. and M. Fishbein: (1980). Understanding Attitudes and Predicting Social Behavior (PrenticeHall, Englewood Cliffs, New Jersey).

Ajzen, I. and T. J. Madden. (1986). 'Prediction of Goal-Directed Behavior: Attitudes, Intentions, and Perceived Behavioral Control', Journal of Experimental Social Psychology 22, 453-474.

Alter, C., \& Hage, J. (1993) Organizations Working Together. Newbury Park, CA: SAGE.

Amabile, T. M. (1988). A model of Creativity And Innovation In Organizations. In B. Staw \& L. L. Cummings (Eds.), Research In Organizational Behavior, 10, $123-$ 167. JAI.

Amabile, T. M. (1996). Creativity In Context: Update To The Social Psychology Of Creativity. Boulder, CO: Westview.

Ansell, C. \& Gash, A. (2008). Collaborative Governance In Theory And Practice. Journal of Public Administration Research and Theory, 18(4), 543-571. doi:10.1093/jopart/mum032

Bandura, A. (1996). Self-Efficacy: The Exercise Of Control. New York, NY: Freeman.

Bennett, J. and Jayes, S. 1995. Trusting the Team: The Best Practice Guide to Partnering in Beyond Incentive Conflict. Strategic Management Journal, 26(5), 415440.

Chrislip, David, and Carl E. Larson. (1994). Collaborative Leadership: How Citizens And Civic Leaders Can Make A Difference. San Francisco, CA: Jossey-Bass

Collins, M. A., \& Amabile, T. M. (1999). Motivation and Creativity. In R. J. Sternberg, Handbook of Creativity, 297-312. New York: Cambridge University Press.

Connelly, C. E dan Kelloway, E.K. (2003). "Predictors of Employee's of Knowledge Sharing Cultures". Journal of Leadership \& Organizational Development, 24(5), 294-301

Crook, C. (2000). Motivation And The Ecology Of Collaborative Learning. In R. Joiner, K. Littleton, D. Faulkner \& D. Miell (Eds.), Rethinking Collaborative Learning. London:Free Association Books

Deci, E.L. and Ryan, R.M. (1985). Intrinsic Motivation and Self-Determination in Human Decision Processes, 50, $179-211$.

Dembo, M. \& Eaton, M. 1997. School Learning And Motivation. In G. Phye (Ed.), Handbook

DSD. (2011). Rationalizing the Implementation of Technical Education and Vocational Training (TEVT) Final Report, 15-19. Putrajaya, Malaysia. 
DSD (2006). Annual Report MLVK 2005. DSD : National Dual Training Systems Division.

DSD (2012a). SkillsMalaysia Partnership Program: Annual Report 2012,7-12. Putrajaya.

DSD. (2012b). Study Recruitment Graduates of the National Dual Training System (NDTS) in Nature Works.. Putrajaya.

DSD. (2012c). The involvement of GLCs and MNCs in the National Dual Training System Program. Putrajaya.

English, Mary. (2000). Who are The Stakeholders In Environmental Risk Decisions?Risk: Health, Safety \& Environment, 11, 243-54.

Erik-Hans Klijn (2008). Governance and Governance Networks in Europe, Public Management Review, 10:4, 505-525, DOI: 10.1080/14719030802263954

Esteve, M., G. Boyne, V. Sierra, and T. Ysa. (2013). “'Organizational Collaboration in the Public Fifth Edition. Upper Saddle River: New Jersey, Pearson Prentice Hall.

Flynn, M., Dooley, L., O’Sullivan, D., \& Cormican, K. (2003). Idea management for Free Association Books

George, J.M., \& Jones, G.R. (2008). Understanding and Managing Organizational Behavior. Fifth Edition. Upper Saddle River: New Jersey, Pearson Prentice Hall.

George, T. 2007. “National Dual Training Systems : Handbook on Social Skills and Social Values in Technical Education and Vocational Training.” Edisi kedua. Serdang : Cataloguing in Publication Data

Gerstner, C. R., and D. V. Day.(1994). Cross-Cultural Comparisons Of Leadership Prototypes. Leadership Quarterly, $2,121-34$.

Glanz, K., Rimer, B., Viswanath, K. (2008). Reasoned Action, Planned Behavior, and the Integrated Behavioral Model Health Behavior and Health Education: Theory, Research, and Practice, 4, 67-96. New York City: John Wiley and Sons.

Gray, B. (1989). Negotiation: Arenas for Reconstructing Meaning. Unpublised Working Paper, Pennsylvania State University Center for Research in Conflict and Negotiation

Gulati, R. (2007). Managing Network Resources: Alliances, Affiliations And Other Relational Assets. Oxford, UK: Oxford University Press.

Gulati, R., \& Singh, H.(1998). The Architecture Of Cooperation: Managing Coordination Costs And Appropriation Concerns In Strategic Alliances. Administrative Science Quarterly, 43(4), 781-814.

Gunton, Thomas I., and J. C. Day. (2003). The Theory And Practice Of Collaborative Planning In Resource And Environmental Management. Environments, 31(2), $5-19$

Hackman, J. R., \& Oldham, G. R. (1980). Work Redesign. Reading, MA: AddisonWesley.

Heath, C., \& Staudenmayer, N. (2000). Coordination Neglect: How Lay Theories Of Organizing Complicate Coordination In Organizations. Research in Organizational Behavior, 22, 153-191.

Hennessey, B. A. (2000). Rewards And Creativity. In C. Sansone \& J. M. Harackiewicz (Eds.), Intrinsic and Extrinsic Motivation: The Search For Optimal Motivation And Performance, 55-78. New York: Academic.

Hogarth, R. 1987. Judgement and Choice (2nd ed.). New York: Wiley

Howard, M., Vidgen, R., \& Powell, P. (2006). Automotive e-Hubs: Exploring Motivations And Barriers To Collaboration And Interaction. The Journal of Strategic Information Systems, 15(1), 51-75.

Kanter, R. M. (1968). Commitment and Social Organization: Study Of Commitment Mechanisms In Utopian Communities. American Sociological Review, 33, 499-51

Kim, T. W. (2010). Barriers to Collaborating Activities among Policy Actors in Industry-Academia Collaboration Policies. International Review of Public Administration, 15(1), 69-80. doi:10.1080/12294659.2010.10805167

Klinger, E. (2006). Conceptual Framework And Issues For A Goals-Oriented Treatment Perspective: A Commentary On "Where Do We Go From Here? The Goal Perspective In Psychotherapy." Clinical Psychology: Science and Practice, 13, 371-374

Kretschmer, T., \& Puranam, P. (2008). Integration Through Incentives Within Different-Tiated Organizations. Organization Science, 19(6), 860-875.

Lepper, M. R. and Greene, D. (1978). "Over Justification Research And Beyond: Toward A Means-Ends Analysis Of Intrinsic And Extrinsic Motivation”. In The Hidden Costs Of Reward: New Perspectives On The Psychology Of Human Motivation, Edited by: Lepper, M. R. and Greene, D. 109-148. Hillsdale, NJ Erlbaum.

Lindenmann, W. K. (2002). Guidelines For Measuring The Effectiveness Of PR Programs And Activities. Gainesville, FL: Institute for Public Relations

Loose, G., Spottl, G. dan Yusoff Md Sahir (2008). "Re-Engineering Dual Training-The Malaysian Experience." German: Peter Lang Publishing.

Malairaja, C., Zawdie, G.(2008)Science Parks And University-Industry Collaboration in Malaysia. Technology Analysis and Strategic Management, , 20: 727-739.

Margerum, Richard D. (2001). Organizational Commitment To Integrated And Collaborative Management: Matching Strategies To Constraints. Environmental Management 28:421-31.

Mitchell, T. R. (1982). Motivation: New Directions For Theory, Research, And Practice Academy of Management Review, 7(1), 80-88. doi: $10.5465=$ amr. 1982.4285467

Mitchell, A. A., \& Olson, J. C. (1981). Are Product Attribute Beliefs The Only Mediator Of Advertising Effects On Brand Attitude? Journal of Marketing Research, $18,318-332$

Mowday, R. T., Porter, L. W., \& Steers, R. M. (1982). Employee-Organization linkages: The Psychology Of Commitment, Absenteeism, And Turnover. New York: Academic.

Msanjila, S.S., (2009). On Inter-Organizational Trust Engineering In Networked Collaborations - Modeling And Management Of Rational Trust. ISBN:10:9057761963, ISBN:13:9789057761966.

Msanjila, S. S. \& Afsarmanesh, H. (2011). On Modelling Evolution Of Trust In Organisations Towards Mediating Collaboration. Production Planning \& Control, 22(5-6), 518-537. doi:10.1080/09537287.2010.536623

Murray, S.R. (2003). "A Quantitative Examination to Determine if Knowledge Sharing Activities, Given The Appropriate Media Richness, Lead to Knowledge Transfer and if Implementation Factors Influence The Use of These Knowledge Sharing Activities". Phd. Thesis. Mississippi State University.

NVTC. (2005). Implementation of the National Dual Training System - guides and rules. (2nd ed.). Putrajaya: National Vocational Training Council

Paris, S. \& Turner, J. (1994). Situated motivation. In P. Pintrich, D. Brown \& C. Weinstein (Eds.), Student Motivation, Cognition And Learning: Essays In Honor Of Wilbert Mckeachie. Hove, UK: Lawrence Erlbaum.

Porter, Lyman W. (1968). The Etiology of Organizational Commitment: A Longitudinal Study of Initial Stages of Employee Organization Relationships. Unpublished Manuscript

Provan, K., and P. Kenis. (2008). Modes of Network Governance: Structure, Management, and Effectiveness. Journal of Public Administration Research and Theory 18: 229-252. doi:10.1093/jopart/mum015.

NDTS Q-fact (2010), Department of Skills Development, Cyberjaya

NDTS Q-fact (2015), Department of Skills Development, Cyberjaya

Rahim M. Sail, Abdul Rahman Md Aroff, Asnarulkhadi Abu Samah, Azimi Hamzah, Sidek Mohd Noah dan Zakaria Kasa (2007). National Dual Training Systems : Handbook on Social Skills and Social Values in Technical Education and Vocational Training." Edisi kedua. Jabatan Pembangunan Kemahiran dengan Kerjasama Universiti Putra Malaysia : Kementerian Sumber Manusia

Rast, S., Khabiri, N., Senin, A.A. Evaluation Framework For Assessing University-Industry Collaborative Research And Technological Initiative. Procedia-Social and Behavioral Sciences, 2012. 40: 410-416.

RMK-10, (2010). Tenth Malaysia Plan 2011-2015, Putrajaya: Economic Planning Unit. Jabatan Percetakan Negara.

Robbins, Stephen P., (2005). Organizational Behavior, Upper Saddle River, New Jersey Pearson, Prentice Hall

Rogers, Todd, Beth Howard-Pitney, Ellen C. Feighery, David G. Altman, Jerry M. Endres, and April G. Roeseler. (1993). Characteristics and participant perceptions of Tobacco Control Coalitions In California. Health Education Research, Theory \& Practice 8:345-57

Rosenberg, M. J., \& Hovland, C. I. (1963). Cognitive, Affective, And Behavioral Components Of Attitudes. In M. J. Rosenberg, C. I. Hovland, W. J. McGuire, R. P. Aberlson, \& J. W. Brehm (Eds.), Attitude Organization And Change: An Analysis Of Consistency Among Attitude Components, 1-57. New Haven, CT: Yale University Press.

Ryan, R. M., \& Deci, E. L. (2000). Intrinsic And Extrinsic Motivations: Classic Definitions And New Directions. Contemporary Educational Psychology, $25,54-67$. doi:10.1006/ceps. 19999.1020 
Schmidt, H. dan Alex, L. (1997). The Dual System Of Vocational Education And Training In Germany : Dalam Roderick Millar Dan Jonathan Reuvid (Eds.), Doing Business With Germany. London

Schriesheim, C. A., S. Castro, and C. C. Cogliser. (1999). Leader-member exchange research: A comprehensive review of theory, measurement, and data-analytic techniques. Leadership Quarterly 10:63-113.

Sheldon, Mary E. (1971). "Investments And Involvements As Mechanisms Producing Commitment To The Organization." Administrative Science Quarterly, 1 6: 143150.

Shook, C.R., \& Britianu, C., (2008). Entrepreneurial Intent in a Transitional Economy: an Application of the Theory Planned of Behavior to Romanian Students. International Entrepreneurship Management Journal

Tan, K.Y. (1991). Malaysian Economic And Industrial Outlook 1991/1992. Forum Economic and Business Journal of FMM.

Vangen, Siv, and Chris Huxham. (2003). Enacting Leadership For Collaborative Advantage: Dilemmas Of Ideology And Pragmatism In The Activities Of Partnership Managers. British Journal of Management 14:S61-76

Vangen, S., Hayes, J. P. \& Cornforth, C. (2014). Public Management Review Governing Cross-Sector, Inter- Organizational Collaborations. Public Management Review, 9037(November), 1-26. doi:10.1080/14719037.2014.903658

Weiss, H. M. (2002). Deconstructing Job Satisfaction: Separating Evaluations, Beliefs And Affective Experiences. Human Resource Management Review, 12, 173194.

Woodman, R. W., Sawyer, J. E., \& Griffin, R. W. (1993). Toward A Theory Of Organizational Creativity. The Academy of Management Review, 18, 293-321.

World Bank, (1997). Malaysia: Enterprise Training, Technology And Productivity. Washington D.C: The World Bank.

Yaffee, Steven L., and Julia Wondolleck. (2003). Collaborative Ecosystem Planning Processes In The United States: Evolution And Challenges. Environments, 31 (2): $59-72$ 